14

\title{
Получение нерастворимых в воде пленок из фиброина шелка, исследование их структуры и свойств
}

\author{
(C) Ю.А. Нащекина ${ }^{1,2,4}$, В.С. Коныгина ${ }^{2}$, Е.Н. Попова ${ }^{3}$, В.В. Кодолова-Чухонцева ${ }^{2}$, А.В. Нащекин ${ }^{4}$, \\ B.E. Юдин ${ }^{2,3}$ \\ ${ }^{1}$ Институт цитологии РАН, \\ 194064 Санкт-Петербург, Россия \\ ${ }^{2}$ Санкт-Петербургский политехнический университет Петра Великого, \\ 195251 Санкт-Петербург, Россия \\ ${ }^{3}$ Институт высокомолекулярных соединений РАН, \\ 199004 Санкт-Петербург, Россия \\ ${ }^{4}$ Физико-технически институт им. А.Ф. Иофффе РАН, \\ 194021 Санкт-Петербург, Россия \\ e-mail: nashchekina.yu@mail.ru
}

Поступило в Редакцию 16 августа 2021 г.

В окончательно редакции 13 сентября 2021 г.

Принято к публикации 13 сентября 2021 г.

Отработаны условия получения нерастворимого в воде фиброина шелка в виде пленок. С помощью оптической микроскопии продемонстрировано изменение морфологии поверхности пленок, обусловленное структурным переходом в крупно-фрагментированное состояние в результате обработки пленок метиловым спиртом. Методом ИК-Фурье спектроскопии подтвержден конформационный переход фиброина шелка от неупорядоченной структуры необработанной пленки в $\beta$-складчатую структуру. Методом д.-сканирующей калориметрии определена температура стеклования нативной пленки $-216^{\circ} \mathrm{C}$. Исследование механических свойств пленок из фиброина шелка в жидкой среде показало, что их прочность снижается, а эластичность увеличивается почти в 15 раз по сравнению с испытаниями этих же пленок в сухом состоянии.

Ключевые слова: фиброин шелка, метанол, ИК-Фурье спектроскопия, дифференциально-сканирующая калориметрия, термогравиметрический анализ, оптическая микроскопия, механические свойства.

DOI: $10.21883 / J T F .2021 .12 .51787 .238-21$

\section{Введение}

В последние годы в тканевой инженерии все активнее используются материалы природного происхождения благодаря таким их свойствам, как биосовместимость и способность к биодеградации без образования токсичных для организма продуктов их разложения $[1,2]$. Такие природные биополимеры как коллаген, желатин, эластин, альгинаты и хитозан находят достаточно широкое применение в регенеративной медицине и тканевой инженерии, однако имеют ряд недостатков: низкие механическая прочность и эластичность, быстрая или, напротив, слишком длительная биодеградация [3]. Еще одним биополимером, привлекающим в последнее время особое внимание исследователей, является фиброин шелка (SF) [4]. SF - натуральный белок, производимый тутовым шелкопрядом (Bombyx mori), имеет хорошую перспективу использования в тканевой инженерии благодаря совокупности таких свойств, как высокая биосовместимость [5,6], минимальная иммуногенность [7] и контролируемая скорость деградации [8]. $\mathrm{SF}$ используется в регенеративной медицине, например, как основа шовных материалов для восстановления мягких тканей [9]. Кроме того, благодаря своей оптической прозрачности, пленка на основе SF является одним из наиболее перспективных материалов для применения в офтальмологии, например, для восстановления поврежденной роговицы глаза $[10,11]$.

Структурно SF содержит две полипептидные цепи: легкая цепь с молекулярной массой $26 \mathrm{kDa}$ и тяжелая цепь с массой $390 \mathrm{kDa}$, которые ковалентно связаны друг с другом дисульфидными мостиками [12]. В составе тяжелой цепи фиброина присутствуют в основном следующие аминокислотные остатки: глицин (43-46\%), аланин $(25-30 \%)$ и серин $(12 \%)$ [13]. Гидрофобные аминокислотные домены складываются и связываются вместе посредством водородных связей, сил Ван-дерВаальса и гидрофобных взаимодействий, образуя стабильные антипараллельные кристаллические структуры или $\beta$-слои. Оставшаяся часть белка состоит из неповторяющихся гидрофильных аминокислотных остатков, которые образуют $\alpha$-спирали во вторичной структуре [14].

$\mathrm{SF}$ имеет достаточно высокий процент аморфной фазы. Аморфная структура плохо упорядочена, в ней присутствуют слабые межмолекулярные связи, что, с одной стороны, обеспечивает хорошую растворимость фиброина шелка в воде, а с другой стороны, определяет низкие упруго-прочностные свойства материала [15]. Такие низкие механические характеристики существенно ограничивают области применения SF. Однако благода- 
ря возможности фазового перехода при определенных условиях обработки SF из аморфной в кристаллическую $\beta$-складчатую структуру можно существенно улучшать потребительские свойства изделий из SF. Направленным образом изменяя соотношение аморфной и кристаллической фаз SF, можно контролировать его растворимость в воде и, соответственно, набухание, а также его механические свойства и скорость биодеградации. Следует отметить, что контролируемая скорость биодеградации является одним из наиболее важных свойств материалов, используемых в биомедицинских изделиях, поскольку определяет сроки эксплуатации таких изделий [15].

Фазовый переход в SF возможен при взаимодействии с такими веществами, как метиловый, этиловый или изопропиловый спирты $[16,17]$. Изучение структурных изменений SF в процессе его обработки спиртами представляет фундаментальный и прикладной интерес. Кристаллизация давно признана доминирующим процессом, влияющим на физико-химические свойства большинства природных полимеров, в том числе и SF [18]. Целью настоящей работы было изучение структурных переходов аморфной фазы SF в кристаллическую $\beta$-складчатую структуру и формирование на основе полученного биополимера нерастворимых в воде пленок.

\section{1. Экспериментальная часть}

\section{1. Материалы}

\subsection{1. Получение водного раствора SF}

Для получения водного раствора SF использовали хирургические шовные нити (Моснити, Россия). Схема процесса представлена на рис. 1. Нити растворяли в водной смеси на основе $\mathrm{CaCl}_{2}$ (Реактив, Россия), $\mathrm{C}_{2} \mathrm{H}_{5} \mathrm{OH}$ (Реактив, Россия) и $\mathrm{H}_{2} 0$ в молярном соотношении $1: 2: 8$ соответственно. Полученную смесь выдерживали при температуре $75^{\circ} \mathrm{C}$ в течение $2 \mathrm{~h}$ на водяной бане до полного растворения шелка.

Для удаления хлористого кальция раствор диализовали против воды. Смену воды осуществляли 5 раз в течение одних суток. Полученный супернатант центрифугировали.

\subsection{2. Формование пленок}

Самонесущие пленки из водного раствора SF были получены методом литья. Полученный по описанной выше методике (рис. 1) водный раствор SF разливали в чашки Петри из полистирола диаметром $35 \mathrm{~mm}$. Для формования пленок толщиной $50 \mu \mathrm{m}$ на поверхность чашки Петри наносили раствор объемом $3 \mathrm{ml}$ и общей концентрацией $30 \mathrm{mg} / \mathrm{ml}$. Далее пленки высушивали при комнатной температуре в течение трех суток, после чего инкубировали в метаноле (Реактив, Россия). Пленки отмывали от метанола дважды в дистиллированной воде, и с помощью скальпеля отделяли от поверхности чашки.

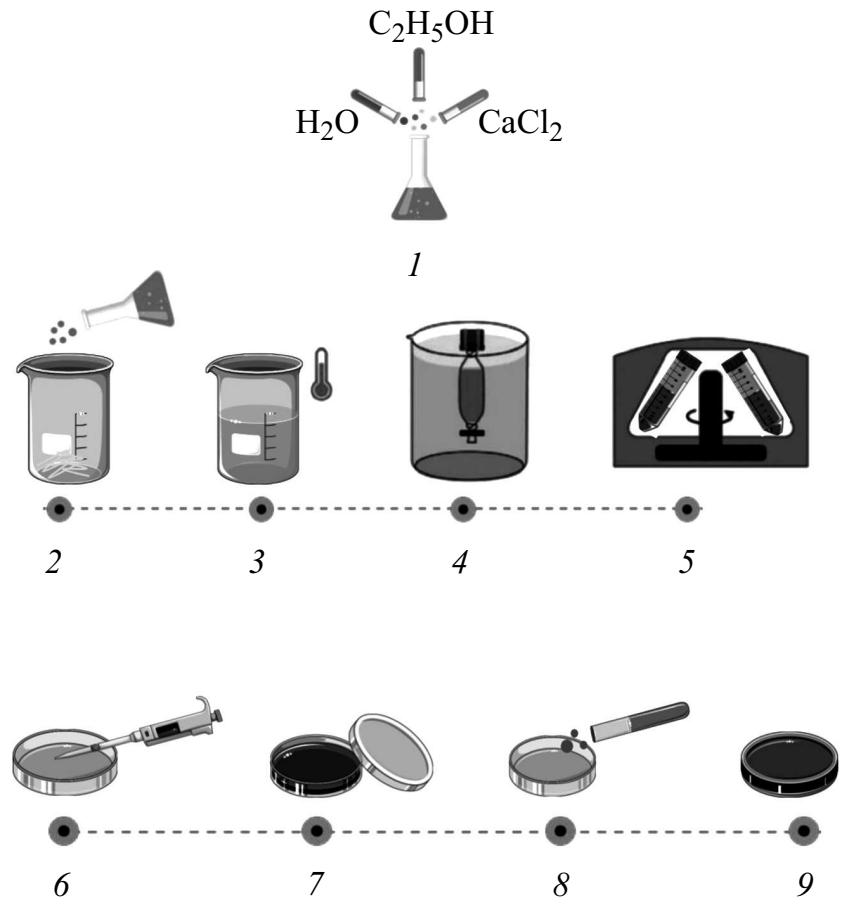

Рис. 1. Схема процесса получения водного раствора $\mathrm{SF}$ из шелковых нитей: 1 - получение растворителя $\mathrm{CaCl}_{2}: \mathrm{C}_{2} \mathrm{H}_{5} \mathrm{OH}: \mathrm{H}_{2} \mathrm{O}$ в молярном соотношении $1: 2: 8 ; 2-$ добавление растворителя к шелковым нитям; 3 - растворение на водяной бане $T=75^{\circ} \mathrm{C}, 2 \mathrm{~h} ; 4$ - диализ раствора $24 \mathrm{~h}$, после смены воды каждые $30 \mathrm{~min} ; 5$ - центрифугирование $3500 \mathrm{rpm} 10 \mathrm{~min}$; 6 - нанесение раствора на чашку Петри; 7 - высушивание при комнатной температуре; 8 - обработка метанолом $2 \mathrm{~h} ; 9$ - промывка дистиллированной водой от метанола.

Пленки в свободном состоянии стерилизовали в 70\% растворе этилового спирта.

\section{2. Методы исследования}

\subsection{1. Оптическая микроскопия}

При исследовании топографии и структуры пленок использовался оптический микроскоп ZEISS Axio Scope.A1 с объективом Epiplan-Neofluar 10x/0.25 HD DIC. Фотографии были получены при 10х увеличении.

\subsection{2. ИК-Фурье спектроскопия}

Молекулярную структуру пленок оценивали с помощью инфракрасного спектрометра с преобразованием Фурье (FTIR) IRPrestige-21 (Shimadzu, Токио, Япония) в режиме отражения в диапазоне от $4000-6000 \mathrm{~cm}^{-1}$ с разрешением $2 \mathrm{~cm}^{-1}$. 


\subsection{3. Дифференциально-сканирующая калориметрия (ДСК)}

Исследования проводили методом ДСК на приборе DSC 204 F1 фирмы NETZSCH (Германия). Температурный диапазон измерений от 25 до $250^{\circ} \mathrm{C}$, при скорости нагрева $10^{\circ} \mathrm{C} / \mathrm{min}$, в инертной среде (аргон). Вес образцов $3-4 \mathrm{mg}$. Расход инертного газа, пропускаемого через образец, - $25 \mathrm{ml} / \mathrm{min}$, расход газа для обдува измерительной ячейки $-70 \mathrm{ml} / \mathrm{min}$. В результате при втором сканировании образцов пленок из SF были определены их температуры стеклования $T_{g}$.

\subsection{4. Термогравиметрический анализ (ТГА)}

Исследования были проведены на установке 209 F1 Iris (NETZSCH, Германия). Образец пленки из SF массой 1-2 mg помещали в керамический тигель и устанавливали в держатель. Измерения проводили в диапазоне температур от 30 до $800^{\circ} \mathrm{C}$ при скорости нагрева $10^{\circ} \mathrm{CC} / \mathrm{min}$ в инертной среде (аргон). Расход инертного газа, пропускаемого через образец, составлял $40 \mathrm{ml} / \mathrm{min}$, расход защитного газа $-25 \mathrm{ml} / \mathrm{min}$. В результате эксперимента ТГА была определена остаточная масса при $800^{\circ} \mathrm{C}$ и рассчитаны температуры 5 и $10 \%$ потери массы $\left(\tau_{5}, \tau_{10}\right)$ с учетом выделившейся влаги.

\subsection{5. Исследование механических свойств полученных образцов}

Исследование механических свойств пленочных образцов из SF проводили на разрывной машине INSTRON 5903 в режиме растяжения со скоростью $5 \mathrm{~mm} / \mathrm{min}$, что позволяет определить их предел прочности, модуль Юнга и деформацию до разрыва. Исследуемые образцы-полоски имели базовую длину $10 \mathrm{~mm}$, ширину $2 \mathrm{~mm}$ и толщину $40-50 \mu \mathrm{m}$. Перед измерением образцы выдерживали в эксикаторе при относительной влажности 96\%, далее испытание проводили при комнатной температуре и относительной влажности $23 \%$.

Исследование механических характеристик на растяжение таких же пленочных образцов-полосок из SF в жидкой среде, имитирующей среду живого организма, проводили с помощью испытательной машины Instron E1000, укомплектованной камерой (биованной) для биореакторной системы LumeGen (Индия). Испытания проводили в жидкой среде (физиологический раствор) при температуре $37 \pm 1^{\circ} \mathrm{C}$. Скорость растяжения образцов составляла $5 \mathrm{~mm} / \mathrm{min}$. Перед началом испытания образцы выдерживались при заданной температуре $5 \mathrm{~min}$.

\section{2. Результаты и их обсуждение}

\section{1. Изучение пленок методом ИК-Фурье спектроскопии}

Перспективность использования скаффолдов (носители или подложки для культивирования и трансплантации клеток) на основе SF для культивирования клеток $\mathrm{c}$ целью их трансплантации в живой организм не вызывает сомнения, поскольку скаффолд вне организма имитирует внеклеточный матрикс, который окружает клетки в процессе их жизнедеятельности в живом организме. Однако благодаря сложному аминокислотному составу и трехмерной структуре, SF имеет как достоинства, например, хорошую биосовместимость, так и недостатки, например, сложность формирования нерастворимых в водной среде скаффолдов с заданными параметрами. $\mathrm{SF}$ является аморфным биополимером, в его вторичной структуре преобладает $\alpha$-спираль, структура которой обеспечивает растворимость SF в воде, и при контакте с живым организмом такие изделия будут просто растворяться. Для формования нерастворимых в воде пленочных скаффолдов необходимо отработать условия инкубирования и обработки пленок из $\mathrm{SF}$ метанолом, поскольку такая обработка вызывает конформационный переход в структуре белка и шелк из неупорядоченной формы с $\alpha$-спиралью приобретает вторичную структуру, а именно кристаллическую $\beta$-складчатость. Механизм кристаллизации обусловлен притяжением полярными группами спиртов воды из молекул SF, что приводит к усиленной агрегации гидрофобных аминокислот, особенно Gly и Ala, во внутренней структуре молекул SF.

Опытным путем было установлено, что для появления конформационных изменений в структуре белка, а, следовательно, для получения нерастворимых в воде пленок, необходимо инкубировать пленки в метаноле не менее $2 \mathrm{~h}$. Пленки, обработанные в метаноле в течение 30, 60 или $90 \mathrm{~min}$ быстро растворялись после погружения их в водную среду.

Для исследования кинетики фазового перехода $\mathrm{SF}$ под влиянием метанола использовали метод ИК-Фурье спектроскопии. Образцы готовились путем нанесения водного раствора SF на отражающую в области ИК металлическую подложку. Время взаимодействия $\mathrm{SF}$ с метанолом регулировали путем изменения объема метанола, наносимого на образец. Чем меньше метанола наносили, тем быстрее он испарялся с поверхности образца, и тем меньше времени отводилось для фазового перехода SF.

Поскольку основным предназначением исследуемых пленок является культивирование клеток, такие пленки должны быть стерильны. Одним из основных способов стерилизации материалов медицинского назначения является обработка их этиловым спиртом. Как было отмечено ранее, этиловый спирт, как и метиловый, способствует фазовому переходу в SF. Поэтому необходимо было провести дополнительные исследования по влиянию последующей обработки этанолом на конформационный переход в SF.

Изменения в структуре пленок из SF, обработанных метанолом и этанолом в разных пропорциях, были исследованы с помощью ИК-Фурье спектроскопии с преобразованием Фурье. Исследуемые образцы из SF: SF-пленки без обработки; SF 10 Methanol - обработка 


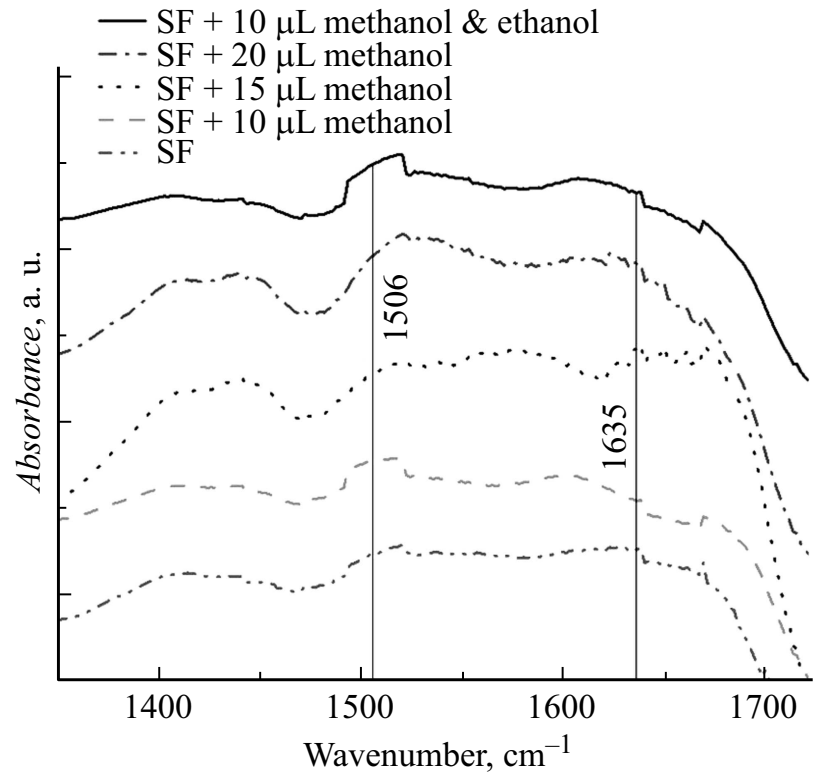

Рис. 2. ИК-фурье спектроскопия сравнения пленок из SF без обработки и с различной обработкой метанолом и этанолом.

$10 \mu 1$ метанола; SF 15 Methanol - обработка $15 \mu 1$ метанола; SF 20 Methanol - обработка $20 \mu 1$ метанола; SF 10 Methanol + 10 Ethanol - обработка $10 \mu 1$ метанола и $10 \mu 1$ этанола.

ИК спектры исходной пленки демонстрируют полосы поглощения при $1652 \mathrm{~cm}^{-1}$ для амида I $(\mathrm{C}=\mathrm{O}$ колебание), $1506 \mathrm{~cm}^{-1}$ для амида II (изгиб $\mathrm{N}-\mathrm{H}$ в плоскости) и $1236 \mathrm{~cm}^{-1}$ для амида III (деформация $\mathrm{N}-\mathrm{H}$ и растяжение $\mathrm{C}-\mathrm{N})$, что характерно для аморфной структуры $[18,19]$. Эти характерные пики поглощения указывают на существование группы $\mathrm{NH}$ с водородными связями $[20,21]$. Наибольший интерес для анализа вторичной структуры белка представляет область спектра амида I, $1600-1700 \mathrm{~cm}^{-1}$, поскольку она наиболее чувствительна к изменению вторичной структуры белка [22]. На рис. 2 представлен ИК спектр SF после обработки раствором метанола и этанола. Присутствие сигналов, характерных для $\beta$-структуры, и увеличение их интенсивности по мере увеличения объема метанола в диапазоне $1625-1630 \mathrm{~cm}^{-1}$ (амид I) и $1520-1530 \mathrm{~cm}^{-1}$ (амид II) свидетельствует о конформационных переходах аморфной структуры в $\beta$-кристаллическую конформацию.

\section{2. Анализ топологии и структуры поверхности пленок}

Для анализа структуры поверхности пленок образцы исследовали с помощью оптической микроскопии. Поскольку для получения нерастворимых в воде пленок используют обработку метанолом и этанолом, было проведено исследование влияния спиртов на структуру поверхности пленок различного состава. На основании данных ИК-Фурье спектроскопии дальнейшие исследования проводили на пленках, подвергшихся максимальному по времени воздействую метанола - инкубированию в течение $2 \mathrm{~h}$. Исходные пленки до обработки спиртами были прозрачными (рис. 3). После инкубирования пленок в $3 \mathrm{ml}$ метанола в течение $2 \mathrm{~h}$ наблюдали фрагментирование пленки, при этом средний размер фрагмента был около $100 \mu \mathrm{m}$. После промывания пленок дистиллированной водой и высушивания структура пленки не менялась. Однако было отмечено, после обработки этанолом размер фрагментов существенно уменьшался и составлял $\sim 5 \mu \mathrm{m}$.

Мы предполагаем, что пленки на поверхности чашки Петри в процессе их обработки метанолом начинают кристаллизоваться, в результате чего происходит их усадка с сопутствующими внутренними напряжениями на поверхности пленки и ее растрескиванием на поверхности (фрагментированием). Внутренняя часть пленки могла остаться аморфной, т.е. более эластичной, поскольку двух часов могло быть недостаточно для диффузии метанола вглубь пленки. Поэтому „фрагментация“ происходит только на небольшую глубину пленки.

\section{3. ДСК}

Согласно данным ДСК (рис. 4), температура стеклования образцов $\mathrm{SF}$ находится в области $188-225^{\circ} \mathrm{C}$. Согласно данным литературы, ДСК SF содержит переход при $228^{\circ} \mathrm{C}$, характерный для сильных молекулярных
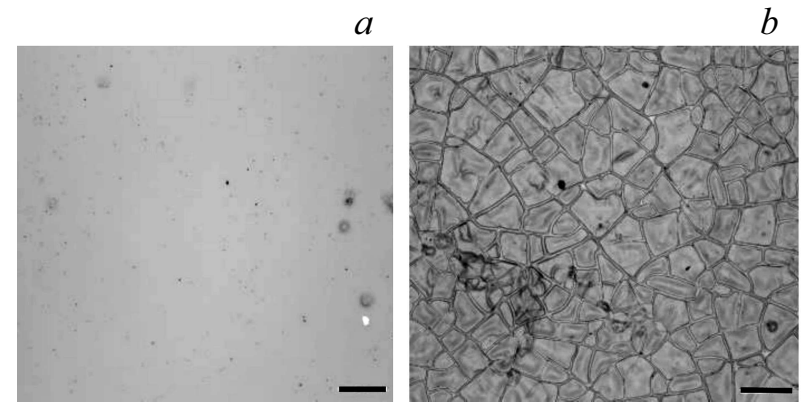

$b$

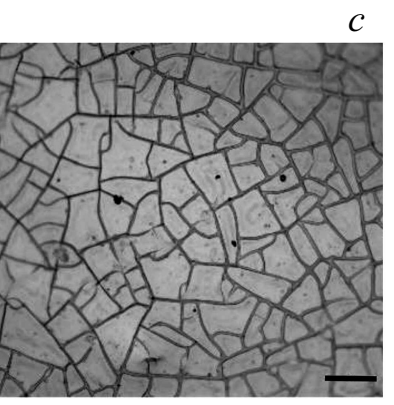

$c$

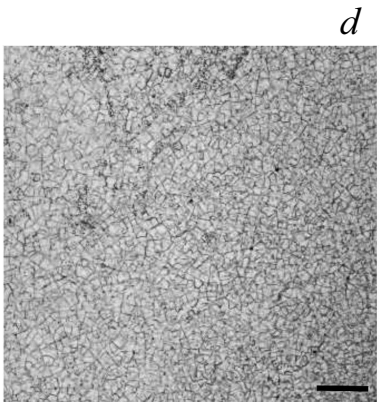

Рис. 3. Оптическая микроскопия пленок. Зависимость структуры поверхности пленок из SF от разных методов обработки: $a-$ исходная пленка; $b-$ пленка после обработки метанолом; $c$ - пленка после обработки метанолом и водой; $d-$ пленка после обработки метанолом, водой и этанолом. Шкала соответствует $100 \mu \mathrm{m}$. 


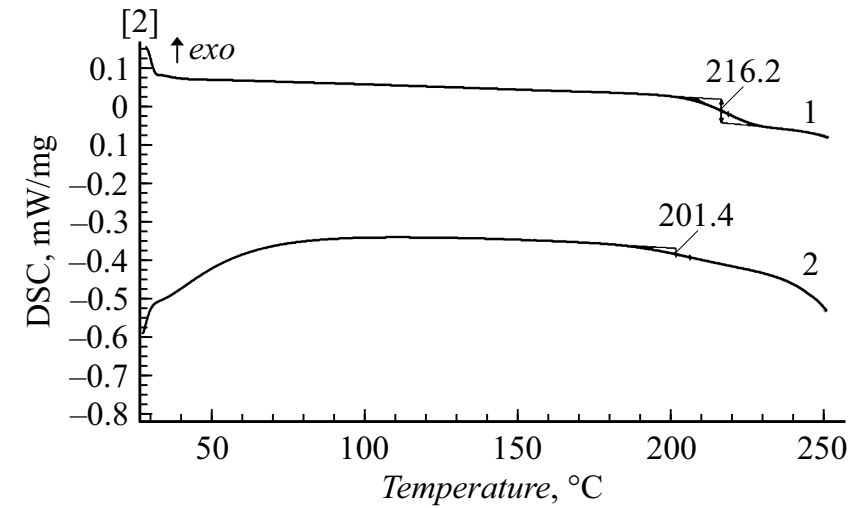

Pис. 4. ДСК кривые: 1 - пленки из чистого SF, 2 - пленки из $\mathrm{SF}$, обработанные метанолом.

движений $\alpha$-кристаллов аморфной фазы [23]. Температура стеклования необработанных пленок на основе SF (образец № 1) составила $216^{\circ} \mathrm{C}$. По данным литературы, температура стеклования необработанного SF может находиться в диапазоне от 213 [22] до $228^{\circ} \mathrm{C}$ [23,24]. Как правило, в результате кристаллизации полимера с помощью метода ДСК весьма трудно определить температуру стеклования, поскольку релаксационные процессы в аморфной части становятся менее выраженными из-за стеснения их кристаллическим каркасом. Кривая ДСК для пленок, обработанных метанолом (образец № 2), в анализируемом диапазоне температур имеет сглаженный характер, свидетельствующий об уменьшении доли $\alpha$-кристаллов. Практически полное исчезновение перехода в данной области для SF, обработанного метанолом, наблюдали авторы и других работ $[25,26]$. При исследовании SF, обработанного метанолом, определение среднего значения $T_{g}$ становится затруднительным, поскольку релаксационный переход становится более размытым.

\section{4. ТГА}

Данные ТГА представлены на рис. 5. Показано, что на кривых ТГА, полученных в инертной атмосфере, в диапазоне температур $30-140^{\circ} \mathrm{C}$ наблюдается потеря массы в количестве 4-7\%, связанная с выходом воды из образцов, причем величина (площадь под кривой) эндотермического пика для SF, обработанного метанолом, несколько меньше, что может свидетельствовать о меньшей сорбционной способности таких пленок по отношению к воде. Уменьшение эндотермического пика также может косвенно свидетельствовать о кристаллизации пленки, обработанной метанолом (обычно кристаллические образцы сорбируют меньше влаги, чем аморфные). Аналогичная закономерность была получена, например, в работе [27]. Область максимальной потери массы SF находится в диапазоне температур $280-340^{\circ} \mathrm{C}$ (рис. 5).

Термостойкость образцов пленок оценивали по значениям индексов термостойкости $\tau_{5}$ и $\tau_{10}$. Можно от- метить, что индексы термостойкости образцов SF, испытанных в инертной атмосфере, имеют очень близкие значения: $\tau_{5}$ в интервале $280-289^{\circ} \mathrm{C}$ и $\tau_{10}$ в интервале $291-302^{\circ} \mathrm{C}$. Согласно работе [28], интенсивный эндотермический пик при этих температурах свидетельствует о термическом разложении SF. Согласно рис. 5, пик ДТГ $\sim 300^{\circ} \mathrm{C}$ - один и тот же для обеих пленок. Поэтому как со стеклованием, так и с термостойкостью $\tau_{5}, \tau_{10}$ у пленок до и после обработки метанолом одни и те же результаты, т.е. эти показатели для обеих пленок одинаковые. И это действительно так, поскольку кристаллизация обычно практически не влияет на эти показатели, но будет влиять на, во-первых, сорбцию воды и во-вторых, на „размытость“ релаксационного переходастеклования из-за появления эндотермического пика плавления, которого мы не видим из-за более ранней по температуре термодеструкции SF. Ориентировочно (по расчетам) температура плавления должна быть не ниже $360^{\circ} \mathrm{C}$, а термодеструкция начинается, согласно рис. 5 , уже при $290^{\circ} \mathrm{C}$.

\section{5. Механические испытания образцов}

Наличие у SF $\beta$-складчатой структуры обеспечивает жесткость пленок, приготовленных из такого биополимера. Однако, в отличие от других материалов, пленки на основе SF имеют тенденцию к увеличению эластичности при контакте с жидкой средой, что является особенно важным фактором при использовании таких пленок в тканевой инженерии и регенеративной медицине [29]. Механические испытания проводили только на пленках, обработанных метанолом, поскольку, как было ранее отмечено, SF - достаточно жесткий и хрупкий материал, но способный увеличивать свою эластичность в водной среде, в которой он будет растворяться без предварительной обработки метанолом. Перед испытаниями в сухом состоянии образцы выдерживали в эксикаторе при относительной влажности 96\% не менее трех дней, поскольку в сухом состоянии такие пленки становятся хрупкими и неэластичными, что затрудняет исследование их механических характеристик.

Полученные данные представлены в виде гистограмм. На рис. 6, a показана зависимость прочности, а на рис. $6, b-$ зависимость деформации до разрыва пленок в сухом состоянии и в жидкой среде. Видно (рис. 6,a), что при контакте с жидкой средой происходит снижение прочностных характеристик пленок. При этом даже во влажном состоянии значения прочности полученных из SF пленок составляют около $30 \mathrm{MPa}$, что заметно больше значений прочности аналогичных пленок, полученных другими исследователями [30]. Как уже упоминалось выше, SF после обработки метанолом в основном состоит из $\beta$-складчатой структуры и аморфных областей. Следовательно, прочность SF в значительной степени зависит от взаимосвязи этих двух фаз. Из литературных данных известно, что вода влияет на структуру и прочность SF [31]. Первоначальные исследования SF 

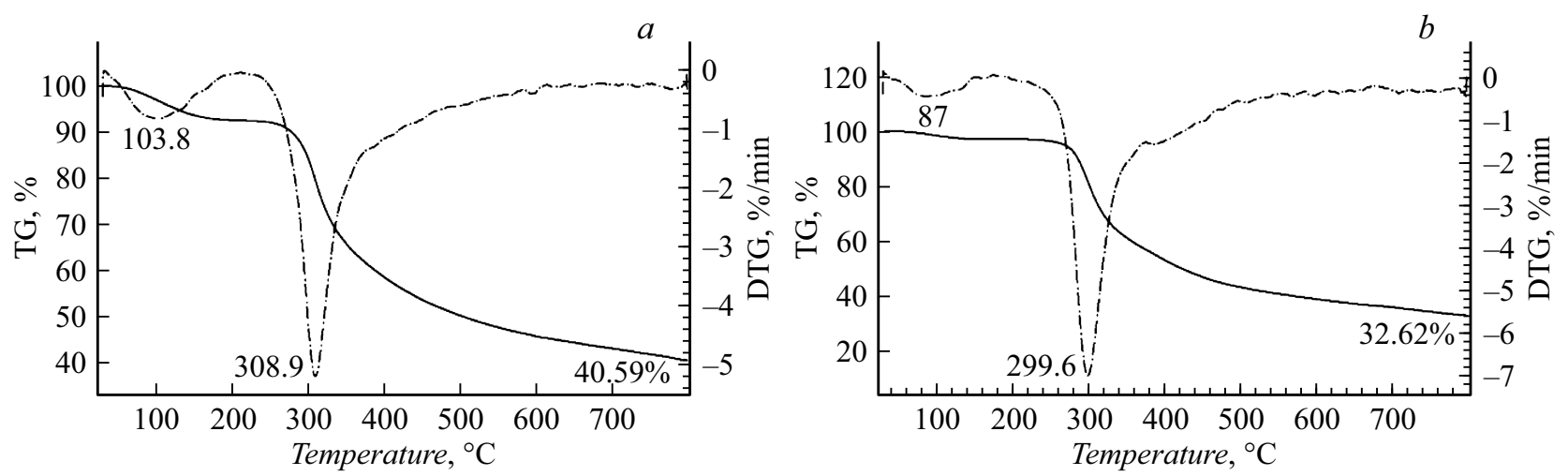

Pис. 5. Термограмма пленок на основе SF: $a$ - исходная пленка; $b-$ после обработки метанолом.
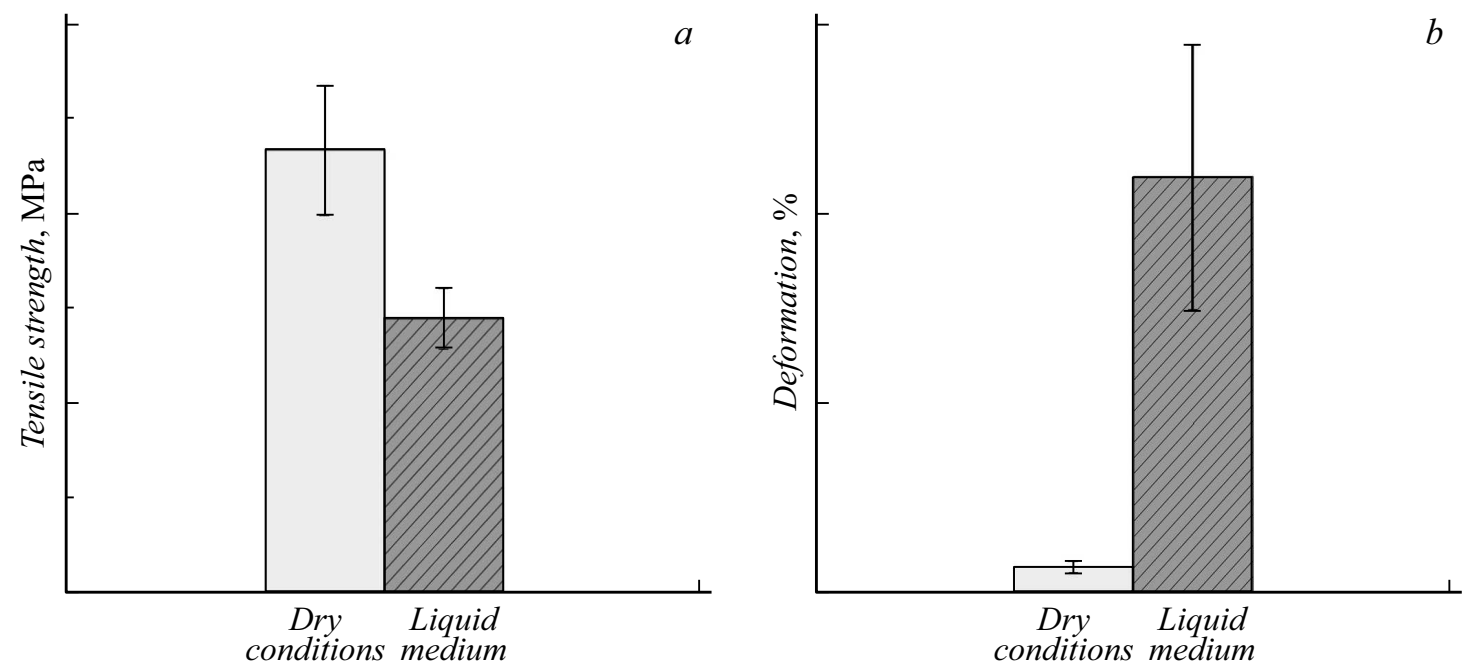

Рис. 6. Механические испытания пленок: $a-$ зависимость прочности пленок из SF от условий испытания; $b-$ зависимость деформации до разрыва пленок из SF от условий испытания.

были в основном сосредоточены на влиянии воды на аморфные домены SF [32], в то время как в последних работах было показано, что вода ослабляет водородные связи между $\beta$-листами в $\mathrm{SF}$, что значительно снижает прочность образцов на его основе [33]. При исследовании структуры SF в присутствии водного растворителя было обнаружено, что молекулы воды препятствуют формированию прочных водородных связей между $\beta$ слоями в кристаллических областях. Таким образом, полученная пленка на основе SF становится более эластичной. Гидрофобные кристаллические $\beta$-слои включены в гидрофильные аморфные области, содержащие влагу. Полипептидные цепи, состоящие из аминокислот, таких, как глицин и аланин, соединенные вместе прочными водородными связями, составляют основные компоненты кристаллических $\beta$-листов [34]. Аморфная фаза существенно снижает прочностные свойства пленок из SF из-за своей неупорядоченной структуры, в то время как кристаллические $\beta$-слои способствуют росту прочности пленок, особенно, во влажном состоянии, что подтверждается также результатами работы [35].

Несмотря на уменьшение прочности пленок из SF, обработанных метанолом, при их испытании в жидкой среде, эластичность их увеличивается почти в 15 раз по сравнению с пленками, испытанных в сухом состоянии (рис. 6,b). Таким образом, при достаточно высокой влажности аморфные участки SF пластифицируются молекулами воды, и эластичность таких пленок увеличивается [36,37]. Действительно, связанная вода разрушает силы межмолекулярного сцепления между белковыми цепями, что приводит к снижению стерических препятствий, которые усиливают движения цепей в аморфных областях и вызывают кристаллизацию $\beta$-пластин в SF.

\section{Заключение}

Получение прочных, эластичных и нерастворимых в воде пленок на основе SF является актуальной задачей современной тканевой инженерии. Исследование кинетики фазового перехода $\alpha$-структур аморфной фазы SF в $\beta$-складчатую структуру позволило получить нерастворимые в воде пленки. С помощью ТГА показано, что пленки после инкубирования в метаноле не только не растворяются воде, но их сорбционная способность к воде ниже по сравнения с пленками до обработки 
метанолом. Немаловажным достоинством полученных пленок является их высокая эластичность, особенно в жидкой среде, которая будет важным преимуществом скаффолдов, предназначенных для тканевой инженерии, поскольку жесткие скаффолды способны травмировать окружающие ткани после трансплантации таких изделий в живой организм.

\section{Финансирование работы}

Работа выполнена при финансовой поддержке РФФИ, проект № 20-03-00400_а.

\section{Конфликт интересов}

Авторы заявляют, что у них нет конфликта интересов.

\section{Список литературы}

[1] Ю.А. Нащекина, О.А. Луконина, Д.М. Дарвиш, А.В. Нащекин, В.Ю. Елоховский, В.Е. Юдин, Н.А. Михайлова. ЖТФ, 90 (9), 1596 (2020). DOI: 10.21883/JTF.2020.09.49697.33-20 [Yu.A. Nashchekina, O.A. Lukonina, D.M. Darvish, A.V. Nashchekin, V.Yu. Elokhovskii, V.E. Yudin, N.A. Mikhailova. Tech. Phys., 65, 1535 (2020). DOI: 10.1134/S1063784220090224]

[2] Ю.А. Нащекина, О.А. Луконина, Н.А. Михайлова. Цитология, 62 (7), 1 (2020). DOI: 10.31857/S0041377120070044

[3] И.П. Добровольская, В.Е. Юдин, П.В. Попрядухин, Е.М. Иванькова. Полимерные матрицы для тканевой инженерии. (Издательско-полиграф. ассоциация университетов России, СПб., 2016)

[4] Ю.А. Нащекина, П.О. Никонов, Н.М. Юдинцева, А.В. Нащекин, А.И. Лихачев, О.А. Москалюк, В.Е. Юдин, М.И. Блинова. Цитология, 58 (11), 843 (2016).

[5] B. Panilaitis, G.H. Altman, J. Chen, H.J. Jin, V. Karageorgiou, D.L. Kaplan. Biomaterials, 24, 3079 (2003).

[6] L. Meinel, S. Hofmann, V. Karageorgiou, C. Kirker-Head, J. McCool, G. Gronowicz, L. Zichner, R. Langer, G. VunjakNovakovic, D.L. Kaplan. Biomaterials, 26, 147 (2005).

[7] H.J. Kim, U.J. Kim, G. Vunjak-Novakovic, B.H. Min, D.L. Kaplan. Biomaterials. 26, 4442 (2005).

[8] Y. Wang, D.D. Rudym, A. Walsh, L. Abrahamsen, H.J. Kim, H.S. Kim, C. Kirker-Head, D.L. Kaplan. Biomaterials, 29, 3415 (2008).

[9] C. Holland, K. Numata, J. Rnjak-Kovacina, F.P. Seib. Adv. Healthc. Mater., 8:e1800465. (2019). DOI: $10.1002 / \mathrm{adhm} .201800465$

[10] M. Parekh, V. Romano, K. Hassanin, V. Testa, R. Wongvisavavit, S. Ferrari, A. Haneef, C. Willoughby, D. Ponzin, V. Jhanji, N. Sharma, J. Daniels, S.B. Kaye, S. Ahmad, H.J. Levis. Tissue Eng., 12, 1 (2021). DOI: $10.1177 / 2041731421990536$.

[11] P. Bhattacharjee, J. Fernández-Pérez, M. Ahearne. Mat. Sci. Eng. C., 105, 110093 (2019). DOI: $10.1016 / \mathrm{j} . \mathrm{msec} .2019 .110093$

[12] Л.А. Сафонова, М.М. Боброва, О.И. Агапова, М.С. Котлярова, А.Ю. Архипова, М.М. Мойсенович, И.И. Агапов. Совр. техн. мед., 7 (3), 6 (2015).

[13] L.D. Koh, Y. Cheng, C.P. Teng, Y.W. Khin, X.J. Loh, S.Y. Tee, M. Low, E. Ye, H.D. Yu, Y.W. Zhang, M.Y. Han. Prog. Pol. Sci., 46, 86 (2015).
[14] Y. Qi, H. Wang, K. Wei, Y. Yang, R.Y. Zheng, I.S. Kim, K.Q. Zhang. Int. J. Mol. Sci., 18 (237), (2017). DOI: $10.3390 /$ ijms 18030237

[15] J.H. Kim, C.H. Park, O.J. Lee, J.M. Lee, J.W. Kim, Y.H. Park, C.S. Ki. J. Biomed. Mater. Res. Part A., 100 (A), 3287 (2012). DOI: $10.1002 / \mathrm{jbm} . a .34274$

[16] L. Jeong, K.Y. Lee, J.W. Liu, W.H. Park. Int. J. Biol. Macromol., 38, 140 (2006). DOI: 10.1016/j.ijbiomac.2006.02.009

[17] D. Terada, Y. Yokoyama, S. Hattori, H. Kobayashi, Y. Tamada. Mater. Sci. Eng., 58, 119 (2016). DOI: 10.1016/j.msec.2015.07.041

[18] K. Yazawa, A.D. Malay, N. Ifuku, T. Ishii, H. Masunaga, T. Hikima, K. Numata. Biomacromolecules, 19(6), 2227 (2018). DOI: 10.1021/acs.biomac.8b00232

[19] S. Kaewpirom. RSC Advances, 10 (27), 15913 (2020). DOI: 10.1039/D0RA02634D

[20] S.W. Ha, A.E. Tonelli, S.M. Hudson. Biomacromolecules, 6 (3), 1722 (2005). DOI: 10.1021/bm050010y

[21] G. Freddi, G. Pessina, M. Tsukada. Int. J. Biol. Macromol., 24 (2-3), 251 (1999). DOI: 10.1016/s0141-8130(98)00087-7

[22] L. Meinel, S. Hofmann, V. Karageorgiou, C. Kirker-Head, J. McCool, G. Gronowicz, L. Zichner, R. Langer, G. VunjakNovakovic, D.L. Kaplan. Biomaterials, 26 (2), 147 (2005). DOI: 10.1016/j.biomaterials.2004.02.047

[23] H. Weon, Y. Park. J. Appl. Pol. Sci., 82, 750 (2001). DOI: 10.1002/app.1901

[24] Q. Lu, X. Hu, X. Wang, J.A. Kluge, S. Lu, P. Cebe, D.L. Kaplan. Acta Biomater., 6, 1380 (2010). DOI: $10.1016 /$ j.actbio.2009.10.041

[25] I.C. Um, H. Kweon, Y.H. Park, S. Hudson. Int. J. Biol. Macromol., 29, 91 (2001). DOI: $10.1016 / \mathrm{s} 0141-8130(01) 00159-3$

[26] Q. Lu, X. Hu, X. Wang, J.A. Kluge, S. Lu, P. Cebe, D.L. Kaplan. Acta Biomater., 6 (4), 1380 (2010). DOI: $10.1016 /$ j.actbio.2009.10.041

[27] A. Sagnella, A. Pistone, S. Bonetti, A. Donnadio, E. Saracino, M. Nocchetti, C. Dionigi, G. Ruani, M. Muccini, T. Posati, V. Benfenati, R. Zambonid. RSC Adv., 6, 9304 (2016).

[28] X. Hu, D.L. Kaplan, P. Cebe. Macromolecules., 3 (9), 6161 (2006). DOI: $10.1021 / \mathrm{ma} 0610109$

[29] Л.А. Сафонова, М.М. Боброва, О.И. Агапова, М.С. Котлярова, А.Ю. Архипова, М.М. Мойсенович, И.И. Агапов. Совр. техн. мед., 7 (3), 6 (2015).

[30] H. Kweon, H.C. Ha, I.C. Um, Y.H. Park. J. Appl. Pol. Sci., 80, 928 (2001). DOI: 10.1002/app.1172

[31] J. Gatesy, C. Hayashi, D. Motriuk, J. Woods, R. Lewis. Science, 291 (5513), 2603 (2001). DOI: $10.1126 /$ science. 1057561

[32] C. Fu, D. Porter, Z. Shao. Macromolecules., 42 (20), 7877 (2009). DOI: $10.1021 / \mathrm{ma} 901321 \mathrm{k}$

[33] Y. Cheng, L.-D. Koh, D. Li, B. Ji, M.-Y. Han, Y.-W. Zhang. J. R. Soc. Interface, 11 (96), 20140305 (2014). DOI: $10.1098 /$ rsif.2014.0305

[34] C.Z. Zhou, F. Confalonieri, M. Jacquet, R. Perasso, Z.G. Li, J. Janin. Bioinform., 44 (2), 119 (2001). DOI: $10.1002 /$ prot. 1078

[35] M. Cetinkaya, S. Xiao, B. Markert, W. Stacklies, F. Gräter. Biophys. J., 100 (5), 1298 (2011). DOI: 10.1016/j.bpj.2010.12.3712

[36] K. Yazawa, K. Ishida, H. Masunaga, T. Hikima, K. Numata. Biomacromolecules, 17 (3), 1057 (2016). DOI: 10.1021/acs.biomac.5b01685

[37] N. Joharia, L. Moroni, A. Samadikuchaksaraei. Eur. Pol. J., 134, (2020). 109842. DOI: 10.1016/j.eurpolymj.2020.109842 